Indah AZ-Landasan Pengembangan Substansi Manajemen Pendidikan Dasar

\title{
LANDASAN PENGEMBANGAN SUBSTANSI MANAJEMEN PENDIDIKAN DASAR DALAM PERSPEKTIF ISLAM
}

\section{Indah Aminatuz Zuhriyah}

\author{
Dosen pada program studi PGMI
}

\begin{abstract}
In order to widespread the best quality of education in elementary education from preliminary to elementary school, it is important to develop the management of education substantion. The aspects of management education substatntion are: 1) curriculum, 2) the student, 3) the teachers, 4) education facilities, 5) education financing, 6) public relation.

This paper discussing only 3 aspects, are: 1) development of curriculum which relates to the basic program of children learning for the 0-12 years old, 2) development of students which relates to effective learning process in order to develop children potential for the preliminary and elementary school year age equally, 3) development of teachers which relates to the teachers capabilities in preliminary and elementary years old. Those three aspects is strengthened by al-Qur`an perspective.
\end{abstract}

Keywords: Management substantion, elementary education

\section{A. Pendahuluan}

Pendidikan menurut Satira (2000), bila dipandang dari sudut visinya merupakan suatu upaya pewarisan nilai-nilai. Nilai-nilai yang dianut dalam komunitas, setidaknya oleh generasi pendahulu untuk diwariskan dan dikembangkan kepada para penerusnya. Nilai-nilai hidup yang dipahami dan dihayati sepanjang hayatnya. Nilai-nilai yang diwariskan tersebut diharapkan dapat meninggalkan generasi penerus yang unggul, tangguh maupun bertahan terhadap berbagai tantangan hidup, maupun dan tenang menghadapi persaingan yang makin ketat, mampu mengembangkan diri dan kemunitasnya sehingga pada gilirannyajuga marnpu mewariskan nilai-nilai yang lebih baik lagi. Bentuk nilai-nilai yang diwariskan diantaranya yang berupa konsep, Ilmu Pengetahuan, nilai-nilai atau norma etika, adat istiadat atau tradisi dan teknologi yang secara langsung maupun tidak langsung dapat mewujudkan tingkat kemajuan yang telah dicapai.

Di pandang dari perangkat dan prosesnya, pendidikan merupakan suatu sistem. Pendidikan memiliki banyak jenis unsur-unsur 
Indah AZ-Landasan Pengembangan Substansi Manajemen Pendidikan Dasar

pembangunnya yang saling berkaitan, saling mempengaruhi, saling membantu dalam mencapai tujuan pendidikan. Ada unsur yang berupa SDM, SDA atau fasilitas dan sarana. Menurut Effendi (2000) subtansi manajemen pendidikan yang lebih rinci disebut yaitu meliputi aspekaspek; (1) kurikulum/pengajaran, (2) siswa, (3) dana pendidikan (fmansial), (4) tenaga pendidikan/guru, (5) sarana/ prasarana pendidikan, dan (6) masyarakat (hubungan sekolah dan masayarakat Humas).

Untuk mewujudkan pendidikan yang bermutu atau berkualitas, substansi manajemen pendidikan diatas sangat perlu ditingkatkan pengembangannya. Terlebih di Lembaga Pendidikan Madrasah, karena dalam sistem pendidikan nasional, madrasah merupakan sub-sistem yang sangat penting. Menurut Satira (2000) bukan hanya karena 17\% dari populasi anak yang bersekolah dimadrasah tetapi madrasah yang lahir jauh lebih dahulu dari republik ini juga mempunyai misi yang unik dalam perjuangan bangsa. Dalam menjawab tantangan zaman, tuntutan untuk mengadakan pembaharuan juga terjadi pada madrasah.

Berdasarkan uraian diatas, tulisan ini akan mengkaji tentang pengembangan substansi manajemen pada tingkat pendidikan dasar dari tingkat RA-MI. Sedangkan substansi manajemen yang dikaji dibatasi pada aspek pengembangan kurikulum (program belajar), pengembangan siswa dan pengembangan tenaga kependidikan dalam hal ini guru. Ketiga aspek tersebut merupakan aspek yang sangat substantif dalam mewujudkan pendidikan yang berkualitas, oleh karenanya perlu untuk terus dikembangkan sesuai dengan kebutuhan zaman.

\section{B. Dasar-dasar Pengembangan Program Belajar yang dapat Memfasilitasi Pengembangan anak usia 0 - 12 tahun}

Pendidikan adalah proses memanusiakan manusia, dengan mengaktualisasikan seluruh potensi manusia menjadi kemampuan yang dapat digunakan dalam kehidupan bermasyarakat. Pendidikan juga rnerupakan proses pemberdayaan siswa (student empowerment), sehingga mereka memiliki fisik normal, intelektual dan emosional (Hasbullah,2006).

Potensi yang harus diaktualisasikan dalam proses pembelajaran yaitu potensi nilai dan sikap (afektif), potensi intelektual (kognitif) dan potensi fisik manual atau potensi Inderawi (motorik atau psikomotorik). Ketiga potensi tersebut selaras dengan apa yang disebut dengan Taksonomi Bloom dan telah di kenal dalam dunia pendidikan.

Dalam Al-Qur'an juga digambarkan tentang potensi dasar yang dimiliki manusia yaitu dalam QS. 16:78 sebagai berikut: 
Indah AZ-Landasan Pengembangan Substansi Manajemen Pendidikan Dasar

"Dan Allah mengeluarkan kamu dari rahim-rahim Ibumu dalam keadaan tiada mengetahui suatu apapun, dan Dia memberi kamu pendengaran, penglihatan dan hati, agar kamu bersyukur " (QS, $16: 78)$.

Maksud dari ayat di atas adalah bahwa bayi yang dilahirkan ke dunia dalam keadaan tidak berdaya secara fisik, tidak mampu merasa dan tidak mampu berfikir, tetapi Allah SWT memberinya potensi Inderawi, dan potensi hati yang terdiri dari potensi IQ, EQ dan SQ agar disyukuri dalam arti diberdayakan atau diaktualisasikan agar menjadi kemampuan yang bermanfaat.

Berdasarkan penjelasan diatas, potensi manusia yang pertama yang harus diaktualisasikan adalah potensi panca indera yang digambarkan dengan pendengaran (telinga) dan penglihatan (mata), tetapi sebenamya meliputi perabaan (tangan), penciuman (hidung) dan rasa (mulut dan lidah). Proses belajar yang dilakukan bayi untuk pertama kalinya adalah belajar melihat, mendengar, merasakan dengan mulutnya mencium dengan hidungnya dan memegang dengan tangannya, kemudian barulah ia belajar berdiri dan berjalan serta berbicara. Sebenamya pada periode awal pertumbuhan (dalam kandungan) bayi sudah belajar berkaitan dengan akualisasi potensi IQ dan EQ.

Potensi selanjutnya adalah hati yang menggambarkan kecerdasan intelektual (IQ), kecerdasan emosional (EQ) dan kecerdasan spiritual (SQ). Potensi kecerdasan spiritual dalam hati digambarkan dalam Al-Quran sebagai berikut:

"Maka hadapkanlah wajahmu dengan lurus kepada Agama (Allah); (tetaplah atas) fitrah Allah yang telah menciptakan manusia menurut fitrah itu. Tidak ada perubahan pada fitrah Allah, itulah agama yang lurus; tetapi kebanyakan manuaia tidak mengetahui" (QS. 30 :30)

Ayat tersebut menggambarkan bahwa lubuk hati manusia yang terdalam yaitu hati sanubari (Consience) adalah fitrah atau suci. Hati sanubari ini tidak bisa berbohong, sehingga dapat dijadikan landasan bagi pensucian hati, berdasarkan nilai-nilai iman dan taqwa. Lapisan kedua setelah lubuk hati adalah qalbu (EQ), dan lapisan terluar dari hati adalah kesadaran manusia yang dapat dibisikan oleh syaithan. Hal itu sebagaimana disebutkan dalam Al-Qur'an berikut:

"Yang membisikkan (kejahatan) kedalam dada manusia"

Lapisan terluar dari hati atau yang disebut kesadaran manusia dilengkapi dengan akal (IQ) dan ingatan atau memori (Cognitive wored). 
Indah AZ-Landasan Pengembangan Substansi Manajemen Pendidikan Dasar

Potensi intelektual (IQ) ini menjadi kecakapan akademik yaitu penguasaan dan pemikiran konsep-konsep dasar keilmuan. Piaget telah menjelaskan bahwa pada usia bayi hingga dua tahun ia sudah belajar melalui sensori motorik, ia mengumpulkan data dimemorinya dari apa yang diterimanya melalui pancaindranya. Pengembangan siswa SD/MI masih didominasi oleh aktualisasi potensi psikomotoriknya (Hasbullah,2006).

Pada usia sekolah dasar, anak sudah dapat mereaksi rangsangan intelektual, atau melaksanakan tugas-tugas belajar yang menuntut kemampuan intelektual atau kemampuan kognitif (seperti: membaca, menulis, dan menghitung atau CALISTUNG). Sebelum masa ini, yaitu masa prasekolah (usia Taman Kanak-Kanak atau Raudatul Athfal), daya pikir anak masih bersifat imajinatif, berangan-angan atau berhayal, sedangkan pada usia SD/MI daya pikirnya sudah berkembang ke arah berpikir kongkrit dan rasional.

Dilihat dari aspek perkembangan kognitif, menurut Piaget (Hasbullah,2006) masa ini berada pada tahap operasi kongkrit, yang ditandai dengan kemampuan (1) mengklasifikasikan (mengelompokkan) benda-benda berdasarkan ciri yang sama, (2) menyusun atau mengasosiasikan (menghubungkan atau menghitung) angka-angka atau bilangan, dan (3) memecahkan masalah (problem solving) yang sederhana.

Kemampuan intelektual pada masa ini sudah cukup untuk menjadi dasar diberikannya berbagai kecakapan yang dapat mengembangkan pola pikir atau daya nalarnya. Kepada anak sudah dapat diberikan dasar-dasar keilmuan, seperti membaca, menulis, dan berhitung (CALISTUNG). Di samping itu, kepada anak juga sudah dapat diberikan dasar-dasar pengetahuan yang terkait dengan kehidupan manusia, hewan, lingkungan alam, lingkungan sosial budaya, dan agama.

Untuk mengembangkan daya nalar, daya cipta, atau kreativitas anak, maka anak perlu diberi peluang-peluang untuk bertanya, berpendapat, atau menilai (memberikan kritik) tentang berbagai hal yang terkait dengan pelajaran, atau peristiwa yang terjadi di lingkungannya.Upaya lain yang dapat dilakukan sekolah, dalam hal ini para guru dalam mengembangkan kreativitas anak, adalah dengan menyelenggarakan kegiatan-kegiatan, seperti perlombaan mengarang, menggambar, menyanyi, kabaret/drama, berpidato (bahasa ibu dan indonesia), dan cerdas-cermat (terkait dengan pelajaran matematika, IPA, IPS, bahasa, dan agama).

Uraian diatas sangat berkaitan dengan konsep islam dalam pengembangan program belajar untuk anak usia 0-12 tahun yang dapat 
Indah AZ-Landasan Pengembangan Substansi Manajemen Pendidikan Dasar

memfasilitasi perkembangan anak secara efektif adalah, hal itu sebagai berikut:

1. Membaca (CA)

Allah SWT telah memerintahkan untuk melakukan pengamatan (mengindera) terhadap alam dan manusia. Hal itu digambarkan dalam surat Al'alaq sebagai berikut:

"Bacalah dengan (menyebut) nama Tuhanmu yang menciptakan; Dia telah menciptakan manusia dari segumpal dar ah" (QS, 96: 1-2).

Kecakapan proses ini menjadi target bagi siswa SD/MI untuk dikuasai dan disebut dengan kecekapan membaci.

2. Menulis (LIS)

Allah SWT dalam surat Al-Qur'an yang sama ayat 3-4 juga memerintahkan untuk menyimpulkan dan menuliskan kesimpulan hasil penginderaan, yang berbunyi sebagai berikut:

"Bacalah, dan Tuhanmulah yang Maha Pemurah; yang mengajar (manusia) dengan perantaraan qalam (pena)" (QS. 96:3-4)

Kecakapan proses ini menjadi target yang kedua bagi siswa SD/MI untuk dilandasi dan disebut dengan kecakapan menulis.

Selain dua konsep dasar diatas, agar siswa SD/MI dapat berfikir secara rasional maka ditambah dengan kecakapan dasar berhitung. Dengan demikian maka target kemampuan yang harus dikuasai di lembaga pendidikan dasar/PD dan PAUD adalah CA-LIS-TUNG.

Dasar-dasar pengembangan program belajar diatas perlu dikelola secara maksimal dan optimal untuk memproses potensi yang dimiliki siswa menjadi suatu kompetensi. Melalui proses pengembangan potensi yang baik dan berkualitas diharapkan siswa memiliki kemampuan yang integral, yaitu mereka yang berilmu, yang mampu mengamalkan ilmunya dalam kehidupan bermasyarakat berdasarkan akhlak mulia. Dengan demikian, dampak akhimya adalah penyebaran rahmat bagi lingkungannya.

C. Proses Pembelajaran yang Efektif untuk Mengembangkan Potensi Anak Usia RA dan MI secara Seimbang.

Proses pembelajaran yang cukup efektif untuk mengembangkan potensi anak usia RA dan MI secara seimbang adalah dengan mendasarkan pada pendidikan yang berorientasi pada generic life skill. Generic life skill merupakan pendidikan berbasis luas atau Broad Based Education (BBE), 
Indah AZ-Landasan Pengembangan Substansi Manajemen Pendidikan Dasar

yaitu pendidikan yang dapat membekali siswa dengan kecakapan generik atau kecakapan hidup yang bersifat umum, yang memungkinkan mereka dapat memasuki dunia kerja dalam bidang keahlian sesuai dengan minat, bakat dan kemampuannya.

Kecakapan generik sendiri adalah kecakapan proses penguasaan dan pemilikan konsep-konsep dasar keilmuan, yang memungkinkan siswa memiliki kemampuan dasar keilmuan atau kemampuan dasar kejuruan. Disamping itu, kecakapan generik juga merupakan kecakapan hidup yang bersifat umum atau general life skill mencakup kecakapan personal dan kecakapan sosial yang bersifat proses. Kecakapan generik menjadi fondasi yang luas yang harus dimiliki siswa untuk dapat memperoleh kemampuan lain yang bersifat mendasar bagi suatu bidang keahlian tertentu.

Kecakapan hidup merupakan muara dari proses pembelajaran seluruh mata pelajaran, baik kelompok mata pelajaran yang berorientasi pada pemilikan nilai dari sikap (afektif), kelompok mata pelajaran yang berorientasi pada pemilikan keilmuan (kognitif) maupun kelompok mata pelajaran yang bersifat psikomotorik. Tujuan pendidikan yang berorientasi pada kecakapan hidup memiliki tiga dimensi, yaitu:

a Dimensi pertama, aadalah tujuan pembelajaran yang berorientasi pada penguasaan dan pemilikan kecakapan proses atau metode (methodological objectives). Kecakapan ini bersifat generik, karena dimiliki oleh semua disiplin ilmu, dan juga merupakan kecakapan prasyarat, karena merupakan kecakapan yang dipersyaratkan untuk dimiliki siswa, agar ia dapat menguasai dan memiliki disiplin ilmu ataupun keahlian kejuruan. Kecakapan ini disebut juga sebagai kecakapan generik atau kecakapan hidup yang bersifat umum (general life skill).

b Dimensi kedua, adalah tujuan pembelajaran yang berorientasi pada penguasaan dan pemilikan konsep dasar keilmuan (content objectives), atau pemilikan materi esensial yang terdiri dari konsep-konsep kunci (key concepts) dan prinsip-prinsip utama (basic principles). Pada umumnya konsep-konsep kunci keilmuan memiliki tingkat generalisasi yang tinggi, sehingga konsep tersebut dapat digunakan dalam disiplin ilmu yang lain (transferable),

c Dimensi ketiga, adalah tujuan pembelajaran yang berorientasi pada kecakapan menerapkan konsep dasar (keilmuan ataupun kejuruan) dalam kehidupan sehari-hari (life skill objectives).

Dimensi tujuan pertama dan kedua tidak dapat diperoleh siswa 
Indah AZ-Landasan Pengembangan Substansi Manajemen Pendidikan Dasar

secara terpisah, ataupun secara berurutan, melainkan harus secara simultan atau bersama-sama. Dalam pembelajaran yang bertujuan agar siswa memiliki kemampuan dasar, terutama untuk anak RA dan MI, maka kegiatan pembelajaran dapat berbentuk proses pembelajaran penemuan. Proses belajar penemuan (discovery atau inquiry), mendorong siswa belajar dan berlatih untuk menguasai kecakapan proses (dimensi pertama) dan juga penguasaan hasilnya yaitu pemilikan konsep dasar keilmuan (dimensi kedua).

Konsep diatas, selaras dengan firman Allah SWT, dalam surat Arra'd dan Surat An-najm yang berbunyi sebagai berikut:

"..... sesungguhnya Allah tidak mengubah keadaan sesuatukaum

sehingga mereka mengubah keadaan yang ada pada diri mereka sendiri ......" (QS. 13:11), dan ayat berikut:

"Dan bahwasannya seseorang tidak akan rnemperoleh selain apa yang telah diusahakannya ..." (QS. 53:39)

Ayat-ayat tersebut diatas, merupakan landasan tentang adanya dua dimensi penguasaan ilmu; pertama dimensi proses, dan kedua dimensi materi serta sekaligus sebagai pembenaran terhadap konsep pembelajaran konstruktivistik. Menurut Bettencourt (Suderajat,2005) pembelajaran konstruktivistik memandang bahwa konsep-konsep keilmuan tidak dapat ditransfer oleh guru kepada siswa, melainkan siswa itu sendiri yang harus mengkonstruksinya menjadi konsep keilmuan, dari data yang diperolehnya melalui panca indera.

Ayat-ayat tersebut juga mengisyaratkan perlunya pembelajaran siswa aktif (student active learning) dan pembelajaran yang berfokus pada siswa (student centered). Orang-orang mungkm diwajibkan untuk belajar secara integral dan menyeluruh (Kaaffah) seperti yang dijelaskan dalam surat Al-Baqorah berikut ini:

"Hai orang-orang yang beriman, masuklah engkau ke dalam Islam secara keseluruhan, dan janganlah kamu turut langkah-langkah syaitan. Sesungguhnya syaitan itu musuh yang nyata bagimu" (QS. 2:208)

Menyeluruh yang dimaksud adalah bahwa dalam pembelajaran siswa harus mengintegrasikan ketiga domain yaitu afektif, kognitif, dan psikomotor, atau iman, ilmu, dan amal. Dengan demikian dimensi dalam pembelaiaran menjadi tiga, yaitu dimensi proses, dimensi materi atau isi, dan dimensi aplikasi.

Kemudian bagaimana proses penguasaan konsep keilmuan itu? 
Indah AZ-Landasan Pengembangan Substansi Manajemen Pendidikan Dasar

Allah SWT mencontohkan bagaimana dia mengajarkan Nabi Adam AS, nama-nama (konsep konkrit) seperti yang dijelaskan dalam Al-Qur'an surat Al-Baqarah yaitu:

"Dan Dia mengajarkan kepada Adam nama-nama (benda-benda) seluruhnya, kemudian mengemukakannya kepada Malaikat lalu berfikir"

"Sebutkanlah kepada Ku nama-nama benda itu jika kamu memang orangorang yang benar" (QS. 2:31).

Proses penguasaan konsep konkrit dalam ayat tersebut merupakan gambaran betapa pentingnya kecakapan proses dalam pembelajaran, khususnya pendidikan dasar karena kecakapan proses merupakan kecakapan generik yang dapat digunakan untuk menguasaan semua bidang keilmuan dan kejuruan, serta dapat dimanfaatkan dalam kehidupan sehari-hari.

Untuk dimensi tujuan ketiga yaitu pembelajaran berorientasi pada pemilikan kecakapan hidup akan terjadi dalam proses pembelajaran yang berwawasan lingkungan (contextual learning). Kecakapan mengaplikasikan ilmu dalam kehidupan sehari-hari memungkinkan seseorang akan mendapatkan perolehan hidup sesuai dengan tingkat keluasan ilmu yang dimilikinya dan tingkat kecakapan mengaplikasikannya dalam kehidupan sehari-hari.

Disamping itu, sebagai penguatan bisa menggunakan rnetode ketauladanan (modelling) dan pembiasaan untuk anak-anak usia 3 sampai 6 tahun (RA). Metode tersebut dapat digunakan terutama dalam penanaman nilai-nilai agama atau nilai-nilai spiritual. Pada masa-masa itu seorang anak memiliki pengalaman agama yang asli dan mendalam, serta mudah berakar dalam diri dan kepribadiannya. Hal tersebut merupakan faktor yang sangat penting melebihi yang lain, karena pada saat itu anak mempunyai sifat wordering atau heran sebagai salah satu faktor untuk memperdalam pemahaman spiritual reality (Hasbullah, 2006).

D. Kompetensi-kompetensi yang harus dimiliki oleh Guru atau Pendidik pada Lembaga PAUD dan PD (RA \& MI).

Merujuk pada Undang-undang Guru dan Dosen dimensi kompetensi yang dibutuhkan adalah dimensi (1) pedagogik, (2) profesional, (3) pribadi, dan (4) sosial. Berikut ini akan diuraikan dimensidimensi kompetensi tersebut.

\section{a Kompetensi Pedagogik}

Dalam Undang-undang No. 14 Tahun 2005 tentang Guru dan Dosen dikemukakan kompetensi pedagogik adalah "kemampuan 
Indah AZ-Landasan Pengembangan Substansi Manajemen Pendidikan Dasar

mengelola pembelajaran peserta didik". Depdiknas (2004:9) menyebut kompetensi ini dengan "kompetensi pengelolaan pembelajaran". Kompetensi ini dapat dilihat dari kemampuan merencanakan program belajar mengajar, kemampuan melaksanakan interaksi atau mengelola proses belajar mengajar, dan kemampuan melakukan penilaian.

1) Kompetensi Menyusun Rencana Pembelajaran

Menurut Joni (1984:12), kemampuan merencanakan program belajar mengajar mencakup kemampuan: (1) merencanakan pengorganisasian bahan-bahan pengajaran, (2) merencanakan pengelolaan kegiatan belajar mengajar, (3) merencanakan pengelolaan kelas, (4) merencanakan penggunaan media dan sumber pengajaran; dan (5) merencanakan penilaian prestasi siswa untuk kepentingan pengajaran.

Depdiknas (2004:9) mengemukakan kompetensi penyusunan rencana pembelajaran meliputi (1) mampu mendeskripsikan tujuan, (2) mampu memilih materi, (3) mampu mengorganisir materi, (4) mampu menentukan metode/strategi pembelajaran, (5) mampu menentukan sumber belajar/media/alat peraga pembelajaran, (6) mampu menyusun perangkat penilaian, (7) mampu menentukan teknik penilaian, dan (8) mampu mengalokasikan waktu.

Berdasarkan uraian di atas, merencanakan program belajar mengajar merupakan proyeksi guru mengenai kegiatan yang harus dilakukan siswa selama pembelajaran berlangsung, yang mencakup: merumuskan tujuan, menguraikan deskripsi satuan bahasan, merancang kegiatan belajar mengajar, memilih berbagai media dan sumber belajar, dan merencanakan penilaian penguasaan tujuan.

2) Kompetensi Melaksanakan Proses Belajar Mengajar

Melaksanakan proses belajar mengajar merupakan tahap pelaksanaan program yang telah disusun. Dalam kegiatan ini kemampuan yang di tuntut adalah keaktifan guru menciptakan dan menumbuhkan kegiatan siswa belajar sesuai dengan rencana yang telah disusun. Guru harus dapat mengambil keputusan atas dasar penilaian yang tepat, apakah kegiatan belajar mengajar dicukupkan, apakah metodenya diubah, apakah kegiatan yang lalu perlu diulang, manakala siswa belum dapat mencapai tujuan-tujuan pembelajaran. Pada tahap ini disamping pengetahuan teori belajar mengajar, pengetahuan tentang siswa, diperlukan pula kemahiran dan keterampilan teknik belajar, misalnya: prinsip-prinsip mengajar, penggunaan alat bantu pengajaran, penggunaan metode mengajar, dan keterampilan menilai hasil belajar 
Indah AZ-Landasan Pengembangan Substansi Manajemen Pendidikan Dasar

siswa.

Yutmini (1992:13) mengemukakan, persyaratan kemampuan yang harus di miliki guru dalam melaksanakan proses belajar mengajar meliputi kemampuan: (1) menggunakan metode belajar, media pelajaran, dan bahan latihan yang sesuai dengan tujuan pelajaran, (2) mendemonstrasikan penguasaan mata pelajaran dan perlengkapan pengajaran, (3) berkomunikasi dengan siswa, (4) mendemonstrasikan berbagai metode mengajar, dan (5) melaksanakan evaluasi proses belajar mengajar.

Hal serupa dikemukakan oleh Harahap (1982:32) yang menyatakan, kemampuan yang harus dimiliki guru dalam melaksanakan program mengajar adalah mencakup kemampuan: (1) memotivasi siswa belajar sejak saat membuka sampai menutup pelajaran, (2) mengarahkan tujuan pengajaran, (3) menyajikan bahan pelajaran dengan metode yang relevan dengan tujuan pengajaran, (4) melakukan pemantapan belajar, (5) menggunakan alat-alat bantu pengajaran dengan baik dan benar, (6) melaksanakan layanan bimbingan penyuluhan, (7) memperbaiki program belajar mengajar, dan (8) melaksanakan hasil penilaian belajar.

Dalam pelaksanaan proses belajar mengajar menyangkut pengelolaan pembelajaran, dalam menyampaikan materi pelajaran harus dilakukan secara terencana dan sistematis, sehingga tujuan pengajaran dapat dikuasai oleh siswa secara efektif dan efisien. Kemampuan-kemampuan yang harus dimiliki guru dalam melaksanakan kegiatan belajar mengajar terlihat dalam mengidentifikasi karakteristik dan kemampuan awal siswa, kemudian mendiagnosis, menilai dan merespon setiap perubahan perilaku siswa.

Depdiknas (2004:9) mengemukakan kompetensi melaksanakan proses belajar mengajar meliputi (1) membuka pelajaran, (2) menyajikan materi, (3) menggunakan media dan metode, (4) menggunakan alat peraga, (5) menggunakan bahasa yang komunikatif, (6) memotivasi siswa, (7) mengorganisasi kegiatan, (8) berinteraksi dengan siswa secara komunikatif, (9) menyimpulkan pelajaran, (10) memberikan umpan balik, (11) melaksanakan penilaian, dan (12) menggunakan waktu.

Dengan demikian, dapat dikatakan bahwa melaksanakan proses belajar mengajar merupakan sesuatu kegiatan dimana berlangsung hubungan antara manusia, dengan tujuan membantu perkembangan dan menolong keterlibatan siswa dalam pembelajaran. Pada dasarnya melaksanakan proses belajar mengajar adalah menciptakan lingkungan dan suasana yang dapat menimbulkan perubahan struktur kognitif 
Indah AZ-Landasan Pengembangan Substansi Manajemen Pendidikan Dasar

para siswa.

3) Kompetensi Melaksanakan Penilaian Proses Belajar Mengajar

Menurut Sutisna (1993:212), penilaian proses belajar mengajar dilaksanakan untuk mengetahui keberhasilan perencanaan kegiatan belajar mengajar yang telah disusun dan dilaksanakan. Penilaian diartikan sebagai proses yang menentukan betapa baik organisasi program atau kegiatan yang dilaksanakan untuk mencapai maksudmaksud yang telah ditetapkan.

Commite dalam Wirawan (2002:22) menjelaskan, evaluasi merupakan bagian yang tidak terpisahkan dari setiap upaya manusia, evaluasi yang baik akan menyebarkan pemahaman dan perbaikan pendidikan, sedangkan evaluasi yang salah akan merugikan pendidikan.

Tujuan utama melaksanakan evaluasi dalam proses belajar mengajar adalah untuk mendapatkan informasi yang akurat mengenai tingkat pencapaian tujuan instruksional oleh siswa, sehingga tindak lanjut hasil belajar akan dapat diupayakan dan dilaksanakan. Dengan demikian, melaksanakan penilaian proses belajar mengajar merupakan bagian tugas guru yang harus dilaksanakan setelah kegiatan pembelajaran berlangsung dengan tujuan untuk mengetahui tingkat keberhasilan siswa mencapai tujuan pembelajaran, sehingga dapat diupayakan tindak lanjut hasil belajar siswa.

Depdiknas(2004:9) mengemukakan kompetensi penilaian belajar peserta didik, meliputi (1) mampu memilih soal berdasarkan tingkat kesukaran, (2) mampu memilih soal berdasarkan tingkat pembeda, (3) mampu memperbaiki soal yang tidak valid, (4) mampu memeriksa jawaban, (5) mampu mengklasifikasi hasil-hasil penilaian, (6) mampu mengolah dan menganalisis hasil penilaian, (7) mampu membuat interpretasi kecenderungan hasil penilaian, (8) mampu menentukan korelasi soal berdasarkan hasil penilaian, (9) mampu mengidentifikasi tingkat variasi hasil penilaian, (10) mampu menyimpulkan dari hasil penilaian secara jelas dan logis, (11) mampu menyusun program tindak lanjut hasil penilaian, (12) mengklasifikasi kemampuan siswa, (13) mampu mengidentifikasi kebutuhan tindak lanjut hasil penilaian, (14) mampu melaksanakan tindak lanjut, (15) mampu mengevaluasi hasil tindak lanjut, dan (16) mampu menganalisis hasil evaluasi program tindak lanjut hasil penilaian.

\section{b Kompetensi Profesional}

Menurut Undang-undang No. 14 tahun 2005 tentang Guru dan 
Indah AZ-Landasan Pengembangan Substansi Manajemen Pendidikan Dasar

Dosen, kompetensi profesional adalah " kemampuan penguasaan materi pelajaran secara luas dan mendalam". Surya (2003:138) mengemukakan kompetensi profesional adalah berbagai kemampuan yang diperlukan agar dapat mewujudkan dirinya sebagai guru profesional. Kompetensi profesional meliputi kepakaran atau keahlian dalam bidangnya yaitu penguasaan bahan yang harus diajarkannya beserta metodenya, rasa tanggung jawab akan tugasnya dan rasa kebersamaan dengan sejawat guru lainnya. Gumelar dan Dahyat (2002:127) merujuk pada pendapat Asian Institut for Teacher Education, mengemukakan kompetensi profesional guru mencakup kemampuan dalam hal (1) mengerti dan dapat menerapkan landasan pendidikan baik filosofis, psikologis, dan sebagainya, (2) mengerti dan menerapkan teori belajar sesuai dengan tingkat perkembangan perilaku peserta didik, (3) mampu menangani mata pelajaran atau bidang studi yang ditugaskan kepadanya, (4) mengerti dan dapat menerapkan metode mengajar yang sesuai, (5) mampu menggunakan berbagai alat pelajaran dan media serta fasilitas belajar lain, (6) mampu mengorganisasikan dan melaksanakan program pengajaran, (7) mampu melaksanakan evaluasi belajar dan (8) mampu menumbuhkan motivasi peserta didik.

Johnson sebagaimana dikutip Anwar (2004:63) mengemukakan kemampuan profesional mencakup (1) penguasaan pelajaran yang terkini atas penguasaan bahan yang harus diajarkan, dan konsepkonsep dasar keilmuan bahan yang diajarkan tersebut, (2) penguasaan dan penghayatan atas landasan dan wawasan kependidikan dan keguruan, (3) penguasaan proses-proses kependidikan, keguruan dan pembelajaran siswa. Arikunto (1993:239) mengemukakan kompetensi profesional mengharuskan guru memiliki pengetahuan yang luas dan dalam tentang subject matter (bidang studi) yang akan diajarkan serta penguasaan metodologi yaitu menguasai konsep teoretik, maupun memilih metode yang tepat dan mampu menggunakannya dalam proses belajar mengajar.

Depdiknas (2004:9) mengemukakan kompetensi profesional meliputi (1) pengembangan profesi, pemahaman wawasan, dan penguasaan bahan kajian akademik. Pengembangan profesi meliputi (1) mengikuti informasi perkembangan iptek yang mendukung profesi melalui berbagai kegiatan ilmiah, (2) mengalihbahasakan buku pelajaran/karya ilmiah, (3) mengembangkan berbagai model pembelajaran, (4) menulis makalah, (5) menulis/menyusun diktat pelajaran, (6) menulis buku pelajaran, (7) menulis modul, (8) menulis karya ilmiah, (9) melakukan penelitian ilmiah (action research), (10) 
Indah AZ-Landasan Pengembangan Substansi Manajemen Pendidikan Dasar

menemukan teknologi tepat guna, (11) membuat alat peraga/media, (12) menciptakan karya seni, (13) mengikuti pelatihan terakreditasi, (14) mengikuti pendidikan kualifikasi, dan (15) mengikuti kegiatan pengembangan kurikulum. Pemahaman wawasan meliputi (1) memahami visi dan misi, (2) memahami hubungan pendidikan dengan pengajaran, (3) memahami konsep pendidikan dasar dan menengah, (4) memahami fungsi sekolah, (5) mengidentifikasi permasalahan umum pendidikan dalam hal proses dan hasil belajar, (6) membangun sistem yang menunjukkan keterkaitan pendidikan dan luar sekolah. Penguasaan bahan kajian akademik meliputi (1) memahami struktur pengetahuan, (2) menguasai substansi materi, (3) menguasai substansi kekuasaan sesuai dengan jenis pelayanan yang dibutuhkan siswa.

\section{c Kompetensi Pribadi}

Guru sebagai tenaga pendidik yang tugas utamanya mengajar, memiliki karakteristik kepribadian yang sangat berpengaruh terhadap keberhasilan pengembangan sumber daya manusia. Kepribadian yang mantap dari sosok seorang guru akan memberikan teladan yang baik terhadap anak didik maupun masyarakatnya, sehingga guru akan tampil sebagai sosok yang patut "digugu" (ditaati nasehat/ucapan/ perintahnya) dan "ditiru" (di contoh sikap dan perilakunya).

Kepribadian guru merupakan faktor terpenting bagi keberhasilan belajar anak didik. Dalam kaitan ini, Zakiah Darajat dalam Syah (2000:225-226) menegaskan bahwa kepribadian itulah yang akan menentukan apakah ia menjadi pendidik dan pembina yang baik bagi anak didiknya, ataukah akan menjadi perusak atau penghancur bagi masa depan anak didiknya terutama bagi anak didik yang masih kecil (tingkat dasar) dan mereka yang sedang mengalami kegoncangan jiwa (tingkat menengah). Karakteristik kepribadian yang berkaitan dengan keberhasilan guru dalam menggeluti profesinya adalah meliputi fleksibilitas kognitif dan keterbukaan psikologis. Fleksibilitas kognitif atau keluwesan ranah cipta merupakan kemampuan berpikir yang diikuti dengan tindakan secara simultan dan memadai dalam situasi tertentu. Guru yang fleksibel pada umumnya ditandai dengan adanya keterbukaan berpikir dan beradaptasi. Selain itu, ia memiliki resistensi atau daya tahan terhadap ketertutupan ranah cipta yang prematur dalam pengamatan dan pengenalan.

Dalam Undang-undang Guru dan Dosen dikemukakan kompetensi kepribadian adalah "kemampuan kepribadian yang mantap, berakhlak mulia, arif, dan berwibawa serta menjadi teladan 
Indah AZ-Landasan Pengembangan Substansi Manajemen Pendidikan Dasar

peserta didik". Surya (2003:138) menyebut kompetensi kepribadian ini sebagai kompetensi personal, yaitu kemampuan pribadi seorang guru yang diperlukan agar dapat menjadi guru yang baik. Kompetensi personal ini mencakup kemampuan pribadi yang berkenaan dengan pemahaman diri, penerimaan diri, pengarahan diri, dan perwujudan diri.

Gumelar dan Dahyat (Wasliman,2007) merujuk pada pendapat Asian Institut for Teacher Education, mengemukakan kompetensi pribadi meliputi (1) pengetahuan tentang adat istiadat baik sosial maupun agama, (2) pengetahuan tentang budaya dan tradisi, (3) pengetahuan tentang inti demokrasi, (4) pengetahuan tentang estetika, (5) memiliki apresiasi dan kesadaran sosial, (6) memiliki sikap yang benar terhadap pengetahuan dan pekerjaan, (7) setia terhadap harkat dan martabat manusia. Sedangkan kompetensi guru secara lebih khusus lagi adalah bersikap empati, terbuka, berwibawa, bertanggung jawab dan mampu menilai diri pribadi. Johnson sebagaimana dikutip Anwar (2004:63) mengemukakan kemampuan personal guru, mencakup (1) penampilan sikap yang positif terhadap keseluruhan tugasnya sebagai guru, dan terhadap keseluruhan situasi pendidikan beserta unsur-unsurnya, (2) pemahaman, penghayatan dan penampilan nilai-nilai yang seyogyanya dianut oleh seorang guru, (3) kepribadian, nilai, sikap hidup ditampilkan dalam upaya untuk menjadikan dirinya sebagai panutan dan teladan bagi para siswanya. Arikunto (1993:239) mengemukakan kompetensi personal mengharuskan guru memiliki kepribadian yang mantap sehingga menjadi sumber inspirasi bagi subyek didik, dan patut diteladani oleh siswa.

\section{d Kompetensi Sosial}

Guru yang efektif adalah guru yang mampu membawa siswanya dengan berhasil mencapai tujuan pengajaran. Mengajar di depan kelas merupakan perwujudan interaksi dalam proses komunikasi. Menurut Undang-undang Guru dan Dosen kompetensi sosial adalah "kemampuan guru untuk berkomunikasi dan berinteraksi secara efektif dan efisien dengan peserta didik, sesama guru, orangtua/wali peserta didik, dan masyarakat sekitar". Surya (2003:138) mengemukakan kompetensi sosial adalah kemampuan yang diperlukan oleh seseorang agar berhasil dalam berhubungan dengan orang lain. Dalam kompetensi sosial ini termasuk keterampilan dalam interaksi sosial dan melaksanakan tanggung jawab sosial.

Gumelar dan Dahyat (Wasliman,2007) merujuk pada pendapat 
Indah AZ-Landasan Pengembangan Substansi Manajemen Pendidikan Dasar

Asian Institut for Teacher Education, menjelaskan kompetensi sosial guru adalah salah satu daya atau kemampuan guru untuk mempersiapkan peserta didik menjadi anggota masyarakat yang baik serta kemampuan untuk mendidik, membimbing masyarakat dalam menghadapi kehidupan di masa yang akan datang. Untuk dapat melaksanakan peran sosial kemasyarakatan, guru harus memiliki kompetensi (1) aspek normatif kependidikan, yaitu untuk menjadi guru yang baik tidak cukup digantungkan kepada bakat, kecerdasan, dan kecakapan saja, tetapi juga harus beritikad baik sehingga hal ini bertautan dengan norma yang dijadikan landasan dalam melaksanakan tugasnya, (2) pertimbangan sebelum memilih jabatan guru, dan (3) mempunyai program yang menjurus untuk meningkatkan kemajuan masyarakat dan kemajuan pendidikan.

Johnson sebagaimana dikutip Anwar (2004:63) mengemukakan kemampuan sosial mencakup kemampuan untuk menyesuaikan diri kepada tuntutan kerja dan lingkungan sekitar pada waktu membawakan tugasnya sebagai guru. Arikunto (1993:239) mengemukakan kompetensi sosial mengharuskan guru memiliki kemampuan komunikasi sosial baik dengan peserta didik, sesama guru, kepala sekolah, pegawai tata usaha, bahkan dengan anggota masyarakat.

Berdasarkan uraian di atas, kompetensi sosial guru dalam penelitian ini akan diukur melalui indikator (1) interaksi guru dengan siswa, (2) interaksi guru dengan kepala sekolah, (3) interaksi guru dengan rekan kerja, (4) interaksi guru dengan orang tua siswa, dan (5) interaksi guru dengan masyarakat.

Selain kompetensi di atas, hal yang sangat penting untuk diperhatikan oleh guru atau pendidik pada lembaga PAUD \& PD ini adalah persoalan kewibawaan. Pendidik harus memiliki kewibawaan (kekuasaan batin mendidik) dan menghindari penggunaan kekuasaan lahir, yaitu kekuasaan yang semata-mata didasarkan kepada unsur wewenang jabatan, kewibawaan merupakan ,sesuatu pancaran batin yang dapat menimbulkan pada pihak lain sikap untuk mengakui, menerima, dan menuruti dengan penuh pengertiari atas kekuasaan tersebut.

Kewibawaan mendidik hanya dimiliki oleh mereka yang sudah dewasa. Orang dewasa adalah orang yang marnpu mernpertanggungjawabkan segenap aktivitas yang bertalian dengan statusnya. Yang dimaksud dengan bertanggung jawab adalah 
Indah AZ-Landasan Pengembangan Substansi Manajemen Pendidikan Dasar

kemampuan untuk menyatukan diri dengan norma-norma hidup dan meragakan dalam hidupnya. Bagi orang yang telah dewasa bila melanggar norma. la bersedia menerima tuntutan hukum atas dirinya. Pendidik adalah pendukung norma-noi-ma (pendukung kewibawaan). Dia mempunyai tugas untuk menstransfoimasikan norma-norma atau kewibawaan itu kepada peserta didik.

Menurut Tirtarahardja \& Sulo (2005), ibarat cahaya lampu bagaimana juga suatu kewibawaan dapat memudar jika tidak dirawat dan dibina. Ada 3 dasar kewibawaan yang menurut Langeveld (Tirtarahardja \& Sulo,2005), harus dibina yaitu:

a. Kepercayaan

Pendidik harus percaya bahwa dirinya bisa mendidik dan juga harus percaya bahwa peserta didik dapat dididik.

b. Kasih sayang

Kasih sayang mengandung dua makna yakni penysrahan diri kepada yang disayangi dan pengendalian terhadap yang disayangi. Dengan adanya sifat penyerahan diri maka pada pendidik timbul kesediaan untuk berkorban yang dalam bentuk konkritnya berupa pengabdian dalam kerja. Pengabdian terhadap yang disayangi dimaksudkan agar peserta didik tidak berbuat sesuatu yang merugikan dirinya.

\section{c. Kemampuan}

Kemampuan mendidik dapat dikembangkan melalui beberapa cara, antara lain pengkaji terhadap ilmu pengetahuan kependidikan, mengambil manfaat dari pengalaman kerja, dan lain-lain.

Persoalan diatas selaras dengan anjuran Al-Qur'an surat AnNahl dalam melaksanakan dakwah/mendidik yaitu sebagai berikut:

"Serulah (manusia) kepada jalan Tuhanmu dengan hikmah dan pelajaran yang baik dan bantahlah mereka dengan cara yang baik (QS. 16;125)

Ayat tersebut menunjukkan bahwa dalam mendidik seorang guru atau pendidik hendaknya menggunakan langkah-langkah diatas yaitu dengan memberikan hikmah atau perkataan yang tegas dan benar yang dapat membedakan antara yang hak dengan yang bathil dengan penuh kewibawaan. Jika tidak dapat diterima maka baru dengan menggunakan langkah-langkah selanjutnya.

\section{E. Kesimpulan}


Indah AZ-Landasan Pengembangan Substansi Manajemen Pendidikan Dasar

Dasar-dasar pengembangan program belajar untuk anak usia 0-12 tahun yang dapat memfasilitasi perkembangan anak secara efektif adalah: a) membaca, b) menulis, dan c) berhitung. Proses pembelajaran yang cukup efektif untuk mengembangkan potensi anak usia RA dan MI secara seimbang adalah: a) proses pembalajaran penemuan (discovery atau luquiry) dan pembelajaran konstruktivistik; dan b) proses pembelajaran berwawasan lingkungan (contextual learning) yang juga bisa digunakan dengan metode modeling (keterladanan) dan pembiadaan. Kompetensi yang harus dimiliki oleh guru atau pendidik adalah yang utama persoalan kewibawaan yang mencakup aspek-aspek; a) kepercayaan, b) kasih sayang, dan c) kemampuan. Sedangkan menurut Undang-Undang kompetensi pedagogik, kompetensi kepribadian, kompetensi sosial dan kompetensi profesional.

\section{F. DAFTAR PUSTAKA}

Anwar, Moch. Idochi. (2004). Administrasi Pendidikan dan Manajemen Biaya Pendidikan. Bandung: Alfabeta

AR.Efendi. 2000. Hand Out Dasar-dasar Manajemen Pendidikan. Malang : PPS-UM.

Arikunto, Suharsimi (1993). Manajemen Pengajaran Secara Manusia. Jakarta: Rineka Cipta.

Harahap, Baharuddin. (1983). Supervisi Pendidikan yang Dilaksanakan oleh Guru, Kepala Sekolah, Penilik dan Pengawas Sekolah. Jakarta: Damai Jaya.

Hasbullah. 2006. Dasar-Dasar llmu Pendidikan. Jakarta: PT. Raja Grafindo Persada.

Joni, T. Raka. (1984). Pedoman Umum Alat Penilaian Kemampuan Guru. Jakarta: Dirjen Pendidikan Tinggi Depdikbud.

Satira, Suparno. 2000. Kebijakan Penetapan Kemampuan Dasar (Basic Competence) sehagai Sasaran Proses Pendiclkan Dalam Menyongsong Era Globalisam: (Pemhelajaran Efektif Menuju Peningkatan Mutu Madrasah). IPAM Surabaya \& BEF Depag FKBA. Yogyakarta.

Suderajat. Heri. 2005, Manajemen Peningkatan Mutu Berbasis Sekolah. Bandung: CV Cipta Lekas Grafika.

Surya, Muhammad. (2003). Psikologi Pembelajaran dan Pengajaran. Bandung. Yayasan Bhakti Winaya.

Sutisna, Oteng. (1993). Administrasi Pendidikan Dasar Teoritis dan Praktis Profesional. Bandung. Angkasa.

Syah, Muhibbin. (2000). Psikologi Pendidikan dengan Pendekatan Baru. 
Indah AZ-Landasan Pengembangan Substansi Manajemen Pendidikan Dasar

Bandung: PT Remaja Rosdakarya.

Tirtarahardja, Umar \& La Sulo. Pengantar Pendidikan. Jakarta: PT. Raja Grafindo Persada.

Undang-undang Nomor 20 Tahun 2003 Tentang Sistem Pendidikan Nasional.

UU RI No. 14 Tahun. 2005. Tentang Guru dan Dosen. Bandung: Citra Umbara. Wasliman, Iim. 2007. Problematika Pendidikan Dasar. Bandung: SPs UPI Yutmini, Sri. (1992). Strategi Belajar Mengajar. Surakarta: FKIP UNS.

Wirawan. (2002). Profesi dan Standar Evaluasi. Jakarta: Yayasan Bangun Indonesia \& UHAMKA Press. 